\title{
Importance of feeding for egg production in Calanus finmarchicus and C. glacialis during the Arctic spring
}

\author{
Signe Juul Madsen ${ }^{1}$, Torkel Gissel Nielsen ${ }^{1, *}$, Outi Maria Tervo ${ }^{2}$, Johan Söderkvist ${ }^{1}$ \\ ${ }^{1}$ National Environmental Research Institute, Department of Marine Ecology, Aarhus University Frederiksborgvej 399, \\ PO Box 358, 4000 Roskilde, Denmark \\ ${ }^{2}$ Arktisk Station, PO Box 504, 3953 Qeqertarsuaq, Greenland
}

\begin{abstract}
The vertical distribution and in situ egg production of Calanus finmarchicus and $C$. glacialis were studied in Disko Bay, western Greenland, from winter throughout the spring bloom. The 2 species entered the surface water simultaneously, but their spawning patterns differed significantly. Maximum egg production for C. glacialis of $48 \pm 8$ eggs female ${ }^{-1} \mathrm{~d}^{-1}$ was measured on May 1,2005 in association with the culmination of the bloom, while the highest egg production rate of $C$. finmarchicus of $44 \pm 7$ eggs female ${ }^{-1} \mathrm{~d}^{-1}$ was measured on May 25 after termination of the bloom. During 3 phases of the spring bloom, the impact of starvation and saturating food conditions on the egg production rates of the 2 Calanus species was investigated in the laboratory. Experiments with starved and ad libitum fed females showed a significant difference in the egg production rate between the 2 species, depending on sampling time, i.e. gonad maturity and feeding history. The results showed varying use of saturating food during the 3 phases of the bloom. For $C$. finmarchicus, no effect of food was observed during the first experiment in late April, whereas females collected in early May, during the peak of the spring bloom, responded strongly to changes in food concentration, with egg production which was 3 times higher than that of the starved controls. In contrast, $C$. glacialis responded strongly to food concentration in both late April and early May. The present investigations illustrate that Calanus females from the Disko Bay area continue to produce eggs without food more than twice as long as those reported from other northern populations. This observation could indicate an adaptation to the Disko Bay environment, which has unpredictable ice conditions and consequently large variations in the initiation of the spring bloom.
\end{abstract}

KEY WORDS: Calanus glacialis $\cdot$ C. finmarchicus $\cdot$ Egg production $\cdot$ Starvation $\cdot$ Spring bloom

\section{INTRODUCTION}

Copepods of the genus Calanus are key players in high latitude marine ecosystems. They dominate the mesozooplankton communities, are significant grazers on the primary production (Nielsen \& Hansen 1995, Levinsen \& Nielsen 2002), and constitute an important prey item for numerous fish, bird, and whale populations (Heide-Jørgensen \& Acquarone 2002, Karnovsky et al. 2003). At the same time, Calanus have a role in the supply of high quality food to the benthic communities by acceleration of the vertical flux trough production of large fast-sinking fecal pellets (Pedersen et al. 2006). In Greenlandic waters, 3 species of Calanus dominate the mesozooplankton community during spring and early summer (Madsen et al. 2001, Møller et al. 2005, Nielsen et al. 2007). C. hyperboreus and C. glacialis are true arctic species inhabiting polar waters, while $C$. finmarchicus is a temperate species associated with Atlantic waters (Conover 1988, Hirche et al. 1991). In Disko Bay, western Greenland, the northern border for $C$. finmarchicus and the southern for C. glacialis, the 2 species meet and co-exist (Madsen et al. 2001). The life-history strategies of Calanus are adapted to the arctic, involving hibernation in deep waters during winter followed by an ascent to 
the productive layers in early spring, where spawning, feeding, and refueling of lipid stores take place (Lee et al. 2006). In late summer, first $C$. hyperboreus, then C. glacialis and later C. finmarchicus descend to deep waters. C. glacialis initiates spawning prior to the spring bloom, with gonad maturation and egg production (EP) fueled by internal lipid reserves (Smith 1990). EP reaches a maximum during the spring bloom, when a correlation between EP and chlorophyll a ( $\mathrm{chl}$ a) concentration can be found (Nielsen \& Hansen 1995, Hirche \& Kosobokova 2003). Being a temperate species, $C$. finmarchicus has smaller lipid reserves and depends on food in order to finish gonad maturation and initiate spawning. EP is therefore highly dependent on the phytoplankton concentration, and spawning is initiated after feeding on the phytoplankton spring bloom has begun (Madsen et al. 2001, Niehoff et al. 2002). As C. hyperboreus spawns during winter (Hirche \& Niehoff 1996, Madsen et al. 2001), it was not considered in the present study.

Disko Bay is located at the southern border of the arctic sea ice and is therefore likely to be affected by climatic changes. The break-up of sea ice in Disko Bay normally takes place between April and May, but oscillates considerably from year to year (HeideJørgensen et al. 2007), thereby influencing the timing of the phytoplankton spring bloom (Nielsen \& Hansen 1995, Madsen et al. 2001, Hansen et al. 2003, Thor et al. 2005). As the mechanisms triggering the termination of Calanus winter hibernation are not fully understood (Fiksen 2000, Hansen et al. 2003, Thorisson 2006), it is not yet known to what degree copepods are capable of timing their ascent from deep waters with the occurrence of the spring bloom. Modeling scenarios suggest that a possible mismatch between ascent and ice break-up could result in copepods experiencing periods of starvation or bad food quality. If the ice remains longer than normal, copepods may ascend at a time when no food is available, and if the ice breaks up early, then the phytoplankton bloom has already sedimented, making protozooplankton and ciliates the main food items (Hansen et al. 2003). Starvation experiments with C. finmarchicus (Hirche 1990, Hirche et al. 1997, Niehoff 2000, 2004) and with C. glacialis (Hirche \& Bohrer 1987, Hirche 1989, Hirche \& Kwasniewski 1997, Kosobokova \& Hirche 2001, Hirche \& Kosobokova 2003) have shown a pronounced decrease in reproductive activity following even short periods of starvation. Knowledge about the sensitivity of reproduction in relation to starvation is therefore crucial for understanding future dynamics of the copepod community in order to quantify their role in the marine food web in a changing environment.
The aim of the present study was to describe the spring migration of the Calanus populations to the surface layer in relation to spring bloom formation in Disko Bay, western Greenland, and to investigate how the surface food conditions on arrival influence EP rate of the 2 co-occurring copepod species C. finmarchicus and C. glacialis during 3 phases of the spring bloom development.

\section{MATERIALS AND METHODS}

Study site. Sampling was conducted from RV 'Porsild' (Arctic Station, University of Copenhagen) in the Disko Bay area close to Qeqertarsuaq in western Greenland from February 22 to May 30, 2005. The sampling was carried out at the permanent station located 1 nautical mile off Qeqertarsuaq (69 $15^{\prime} \mathrm{N}, 53^{\circ} 33^{\prime} \mathrm{W}$ ) (Fig. 1), previously used for studying the pelagic community (Nielsen \& Hansen 1995, Hansen et al. 1999, Madsen et al. 2001, Levinsen \& Nielsen 2002, Thor et al. 2005, Pedersen et al. 2006). From February 22 to May 30, weekly cruises were made to the permanent station, where CTD profiles, chl $a_{1}$, nutrient, and stratified copepod samples were taken. From late April to the end of May, additional measurements of Calanus finmarchicus and C. glacialis EP were included in the program.

Hydrography and nutrients. The vertical distribution of salinity and temperature was measured down to $80 \mathrm{~m}$ using a Seabird SBE25-01 CTD. Water samples from 1, 15, 30, 50, and $100 \mathrm{~m}$ were taken using a Niskin $10 \mathrm{l}$ water bottle, and stored in dark $10 \mathrm{l}$ plastic containers. Subsamples of $10 \mathrm{ml}$ for determination of nutrient concentration were frozen immediately after sampling. The nutrient concentrations were later analyzed at the National Environmental Research Institute (NERI) on an automatic nutrient analyzer (Dansk Havteknik) following Grasshoff (1976). All nutrient samples were analyzed in duplicate with a precision of $0.06,0.1,0.3$, and $0.2 \mu \mathrm{M}$ for phosphorus, nitrate, ammonia, and silicate, respectively.

Phytoplankton. Three samples of $500 \mathrm{ml}$ were filtered onto GF/F filters. Chl a was extracted overnight in $5 \mathrm{ml} 96 \%$ ethanol (Jespersen \& Christoffersen 1987) and measured before and after acid addition on a Turner Designs Model 700 Fluorometer calibrated against a pure chl a standard. Phytoplankton biomass was calculated from chl $a$, applying a C/chl a conversion factor of 42.8 (Pedersen et al. 2006).

Ciliates and heterotrophic dinoflagellates. The abundance and species composition of ciliates and heterotrophic dinoflagellates were quantified in $100 \mathrm{ml}$ seawater from 1 and $15 \mathrm{~m}$ depth, preserved in Lugol's solution ( $2 \%$ final concentration). The samples were allowed to settle for $24 \mathrm{~h}$ in $50 \mathrm{ml}$ chambers, prior to quantification under an inverted microscope at $200 \times$ 


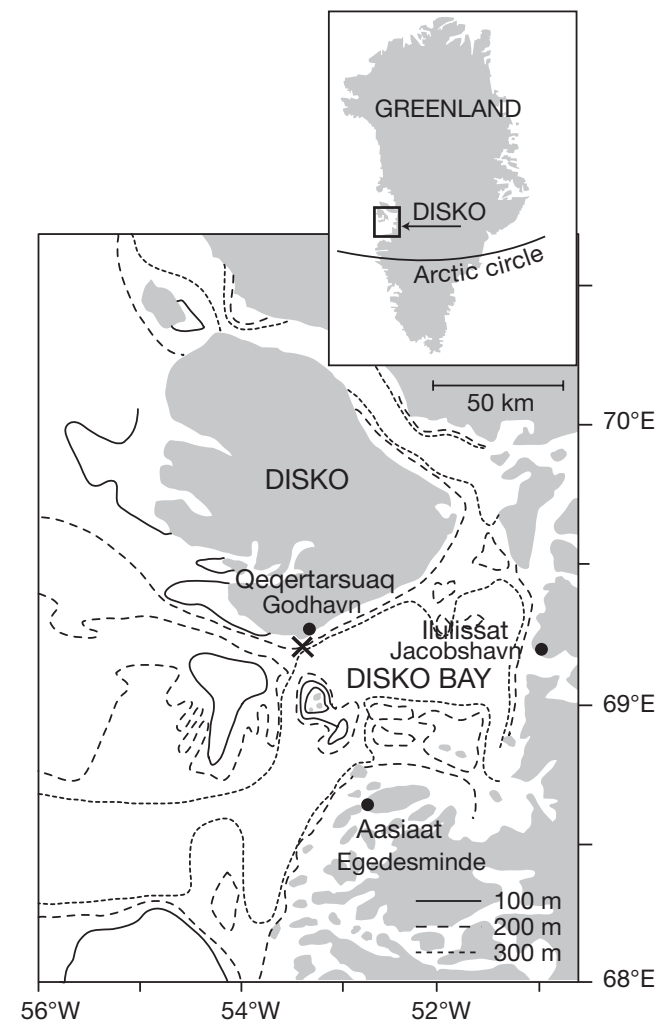

Fig. 1. Location of study site

magnification. The identification of species or morphologic types was based on Nielsen \& Hansen (1999). Cell volume was calculated from measurements of linear dimensions and simple geometric shapes, and the biomass estimated from volume according to equations in Menden-Deuer \& Lessard (2000).

Mesozooplankton. Zooplankton distribution was sampled using a submersible pump (900 l $\mathrm{min}^{-1}$, HOMA-H500, DIFRES design) equipped with a flowmeter (Hydrobios), conical net (50 $\mu \mathrm{m}$ mesh size), and a nonfiltering cod end. Samples were collected in 4 depth strata $(0-50,50-100,100-150$, and $150-200 \mathrm{~m})$. The pump was lowered to deepest part of the strata, switched on, and retrieved to the upper layer at speed $10 \mathrm{~m} \mathrm{~s}^{-1}$ and turned off. From 0 to $50 \mathrm{~m}$, strata triplicate samples were taken on each sampling occasion. The samples were immediately preserved in buffered formalin ( $2 \%$ final concentration) for later analyses. In the laboratory, the samples were split by a plankton splitter to obtain sample sizes of approximately 500 individuals, and all identifiable zooplankters were identified to either species or genus and developmental stage. Prosome lengths were measured on 10 individuals from each copepodite or adult stage of each species. The biomass values of the different copepods were calculated based on measurements of their length in the different depth strata and length-weight regressions from the literature (Thor et al. 2005).

In situ EP. Approximately once a week, live copepods were sampled in the upper $100 \mathrm{~m}$ using a WP-2 net (mesh size $200 \mu \mathrm{m}$ ) and transferred to a $25 \mathrm{l}$ plastic jar and stored under dark and cold conditions. Within $3 \mathrm{~h}, 10$ fertilized females of Calanus glacialis and $C$. finmarchicus were carefully sorted out and individually incubated in $600 \mathrm{ml}$ polycarbonate bottles filled with surface water at in situ temperature. During sorting, the copepod-containing beakers and Petri dishes were kept in trays with ice-cold seawater. The incubation bottles were placed in the cold room in 1001 buckets with snow and seawater to keep the temperature at $0^{\circ} \mathrm{C}$. After 24 to $36 \mathrm{~h}$ incubation, the content of the bottles were concentrated on a $45 \mu \mathrm{m}$ sieve and the female and the eggs rinsed to a counting chamber, where the eggs were counted and length of the females measured. Carbon content in females was estimated from length, using conversion factors found by Nielsen \& Hansen (1995) (Table 1).

Laboratory experiments. On 3 occasions (April 26, May 10, and May 30) representing different phases of the spring bloom (Table 2), additional EP experiments were initiated. Live females were collected as described above, and 2 levels of food concentration were set up for each of the experiments (Expts 1 to 3 ).

EP during starvation: Ten fertilized females of $\mathrm{Ca}$ lanus finmarchicus and C. glacialis were incubated individually in $600 \mathrm{ml}$ polycarbonate bottles with GF/F filtered surface water $\left(0.15 \pm 0.02 \mu \mathrm{g} \mathrm{chl} \mathrm{a} \mathrm{l}^{-1}\right)$.

Table 1. Calanus finmarchicus and C. glacialis. Prosome length and carbon content (mean $\pm \mathrm{SE}$ ) in females collected for in situ measurement of egg production

\begin{tabular}{|lccc|}
\hline Species & Length $(\mu \mathrm{m})$ & Weight $(\mathrm{mg} \mathrm{C})$ & $\mathrm{n}$ \\
\hline C. finmarchicus & $2600 \pm 13.2$ & $0.15 \pm 0.00$ & 150 \\
C. glacialis & $3416 \pm 25.8$ & $0.40 \pm 0.01$ & 120 \\
\hline
\end{tabular}

Table 2. Calanus finmarchicus and C. glacialis. In situ nutrient conditions and pelagic carbon in plankton on the day females were collected for experiments, i.e. prior to addition of Rhodomonas salina, and carbon content (mean $\pm \mathrm{SE}$ ) of the incubated females. BD: below detection limit

\begin{tabular}{|lccc|}
\hline Biomass & Expt 1 & Expt 2 & Expt 3 \\
\hline Nitrate $(\mu \mathrm{M})$ & $6.9 \pm 0.5$ & $\mathrm{BD}$ & $\mathrm{BD}$ \\
Phytoplankton $\left(\mu \mathrm{g} \mathrm{C}^{-1}\right)$ & 298.9 & 532.7 & 176.04 \\
Protozoa $\left(\mu \mathrm{g} \mathrm{C} \mathrm{l}^{-1}\right)$ & 14.7 & 5.1 & 6.6 \\
C. finmarchicus $\left(\mathrm{mg} \mathrm{C} \mathrm{female}^{-1}\right)$ & $0.16 \pm 0.01$ & $0.17 \pm 0.01$ & $0.14 \pm 0.01$ \\
C. glacialis $\left(\mathrm{mg} \mathrm{C} \mathrm{female}{ }^{-1}\right)$ & $0.46 \pm 0.03$ & $0.45 \pm 0.03$ & $0.45 \pm 0.03$ \\
\hline
\end{tabular}


EP at saturated food concentration: Ten females of each species were incubated individually in $600 \mathrm{ml}$ polycarbonate bottles with $45 \mu \mathrm{m}$ screened surface water $\left(9,12\right.$, and $4 \mu \mathrm{g} \mathrm{chl} \mathrm{a} \mathrm{l}^{-1}$ for the 3 experiments, respectively) spiked with a phytoplankton culture (Rhodomonas salina) until an average chl a concentration of $56.2 \pm 6.6 \mathrm{\mu g} \mathrm{chl} \mathrm{a}^{-1}$ was achieved.

On a daily basis, the contents of the bottles were gently concentrated on a $45 \mu \mathrm{m}$ submerged sieve and rinsed to a counting chamber. The females were immediately transferred using a large mouth pipette to new bottles with either fresh GF/F filtered water or diluted Rhodomona salina culture and brought back to the cold room. The spawned eggs were then counted. In order to keep the temperature subzero, all handling of the copepods was done in containers submerged in ice-cold seawater. After 10 to $13 \mathrm{~d}$, the experiments were terminated and the length of the females measured. Results of all experiments are presented as average values $\pm \mathrm{SE}$, unless otherwise stated.

\section{RESULTS}

\section{Hydrography and phytoplankton}

In winter 2005, no permanent ice cover of Disko Bay was formed; hence, when the present investigation was initiated in February, only drift ice was present. Until early April, the temperature in the upper $50 \mathrm{~m}$ was rather homogeneous and $<-1.5^{\circ} \mathrm{C}$ (Fig. 2A). There was a weak salinity difference of about 0.1 from the surface to $100 \mathrm{~m}$ (Fig. 2B) and the chl a concentration was $<0.1$ $\mu \mathrm{g}^{-1}$ (Fig. 2C). In mid-April, an upwelling or inflow of water with higher salinity stratified the surface layer (Fig. 2B), and the shallower mixed layer triggered the plankton bloom (Fig. 2C). From April 8 to May 2, the chl a concentration increased from 1 to $17 \mu \mathrm{g} \mathrm{l}^{-1}$ (Fig. 2C). The nutrients were rapidly consumed by the bloom, after which the bloom gradually settled. In the middle of May, meltwater reduced the mixed-layer salinity and mixed-layer depth down to 33.1 and $5 \mathrm{~m}$, respectively (Fig. 2B). Throughout the winter, the surface chl a concentration was low $\left(0.06 \pm 0.01 \mathrm{\mu g} \mathrm{l}^{-1}\right)$, which lasted until April, when it exceeded $1 \mu^{l^{-1}}$ (Figs. 2C \& 3A). The spring bloom started in mid-April and peaked May 2 at $16.4 \pm 0.4 \mu \mathrm{g} \mathrm{chl} \mathrm{a} \mathrm{l^{-1 }}$, after which chl a concentration rapidly declined, reaching $4.1 \pm 0.9 \mu \mathrm{g} \mathrm{l}^{-1}$ on May 30 , as a result of a nitrate depletion in the photic zone. Small phytoplankton $(<45 \mu \mathrm{m})$ dominated the surface waters from February 25 to April 27, when they contributed on average $81 \pm 6 \%$ to the total phytoplankton biomass. As the bloom developed, a shift in size composition was observed. The proportion of small phytoplankton decreased to an average of $23 \pm 2 \%$, and during the rest of the investigative period, the phytoplankton community was dominated by phytoplankton $>45 \mu \mathrm{m}$ (Fig. 3A). This observation was corroborated by microscopic examination of the plankton, which showed that large diatoms (Thalassiosira spp., Chaetoceros spp., and Detonula spp.) dominated the phytoplankton community during the bloom.

\section{Protozooplankton (ciliates and heterotrophic dinoflagellates)}

The succession of microprotozooplankton followed the development of the phytoplankton community. Heterotrophic dinoflagellates dominated the protozooplankton community, and were responsible for $69 \pm 4 \%$ of the protozooplankton biomass (Fig. 3B,C). Until late April, the protozooplankton biomass was low, and thereafter it followed the developing phyto-
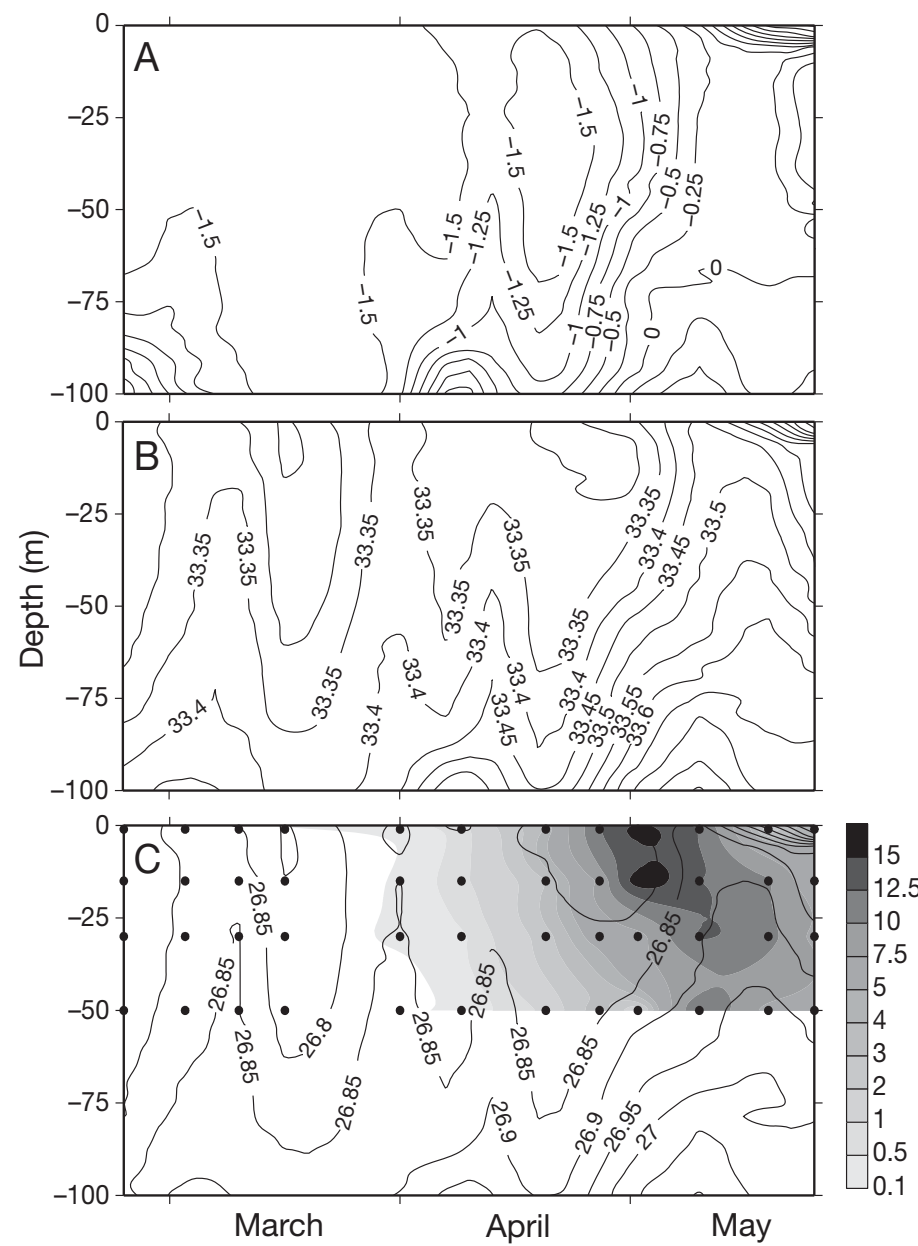

Fig. 2. Depth distribution of (A) temperature $\left({ }^{\circ} \mathrm{C}\right)$, (B) salinity, and (C) density (1000 $\mathrm{kg} \mathrm{m}^{-3}$, lines) and chlorophyll a concentration ( $\mathrm{g} \mathrm{l}^{-1}$, shading) in Disko Bay February 25 to May 30, 2005 
plankton spring bloom (Fig. 3B,C). Dinoflagellates were found to correlate strongly with phytoplankton $<45 \mu \mathrm{m}\left(\mathrm{r}^{2}=0.70, \mathrm{n}=25, \mathrm{p}<0.01\right)$, whereas ciliates correlated weakly with total phytoplankton biomass $\left(\mathrm{r}^{2}=0.34, \mathrm{n}=74, \mathrm{p}<0.05\right)$. Total protozooplankton biomass correlated with phytoplankton $<45 \mu \mathrm{m}\left(\mathrm{r}^{2}=\right.$ $0.72, \mathrm{n}=25, \mathrm{p}<0.01)$. Biomass decreased after a

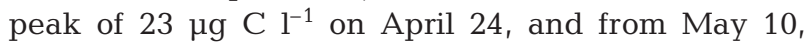
the biomass stabilized at $5 \pm 0.5 \mu \mathrm{g} \mathrm{C}^{-1}$. The contribution of dinoflagellates and ciliates to total protist carbon dropped from $12 \%$ in late February to $2 \%$ in late May. From April 24 to May 30, the average pro-

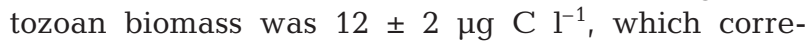
sponded to approximately $3.6 \pm 0.7 \%$ of the total protist biomass.

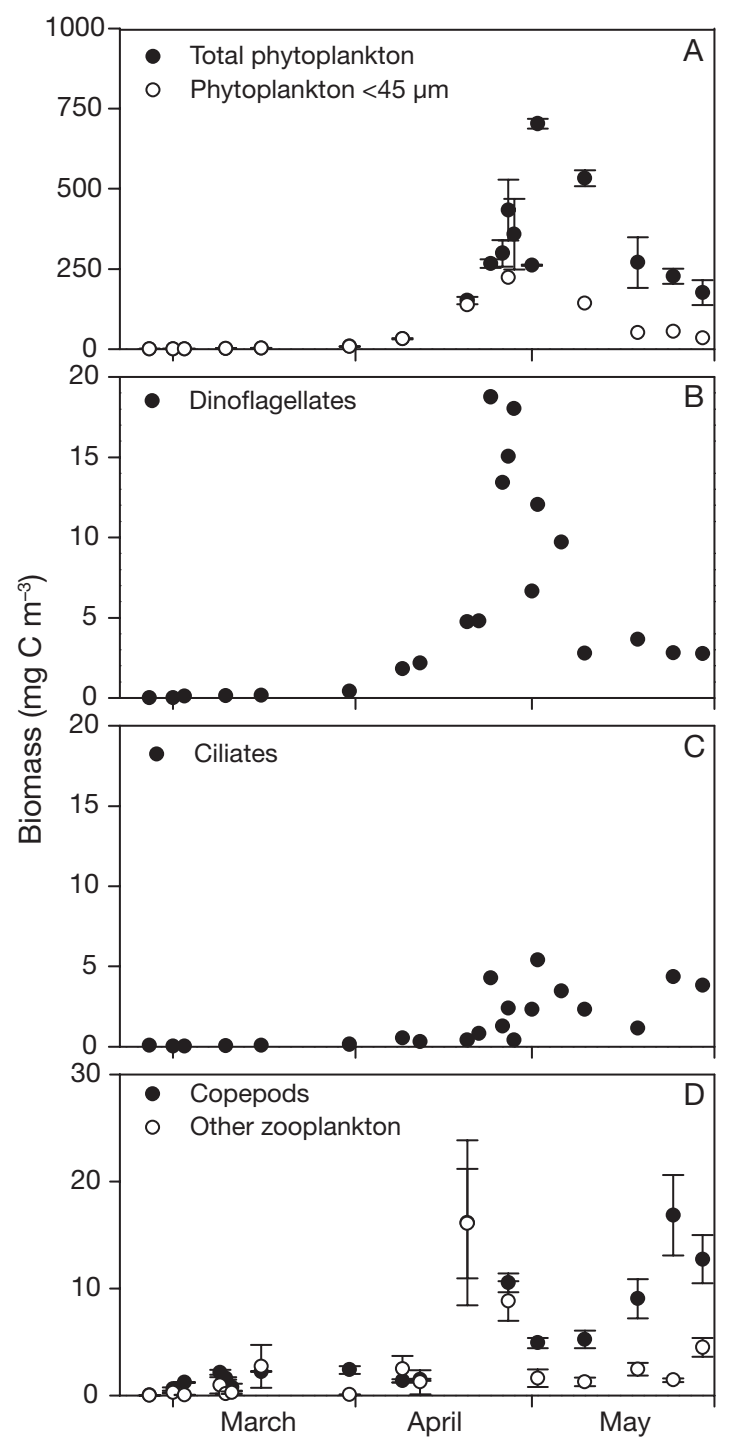

Fig. 3. Biomass of (A) total phytoplankton and phytoplankton $<45 \mu \mathrm{m}$, (B) dinoflagellates, (C) ciliates, and (D) copepods and other zooplankton. Values are means of measurements (A-C) at 1 and $15 \mathrm{~m}$ or (D) in the upper $50 \mathrm{~m}$. Error bars indicate $\pm \mathrm{SE}$

\section{Biomass and depth distribution of the copepod community}

Copepods dominated the mesozooplankton and contributed on average $79 \pm 3 \%$ to total integrated biomass $(0$ to $200 \mathrm{~m}$ ). The biomass included in the group 'other zooplankton' mainly consisted of Clione limacina and Balanus spp. In the upper $50 \mathrm{~m}$, the proportion of copepods in the zooplankton samples was 36 to $97 \%$, and on average $73 \pm 6 \%$ during the investigation (Fig. 3D). The total biomass of copepods and 'other zooplankton' increased gradually from February 25 to April 20 with a maximum biomass of $16 \mathrm{mg} \mathrm{C} \mathrm{m}^{-3}$.

Calanus spp. dominated the copepod biomass at all depth strata (Fig. 4), contributing on average $69 \pm 4 \%$
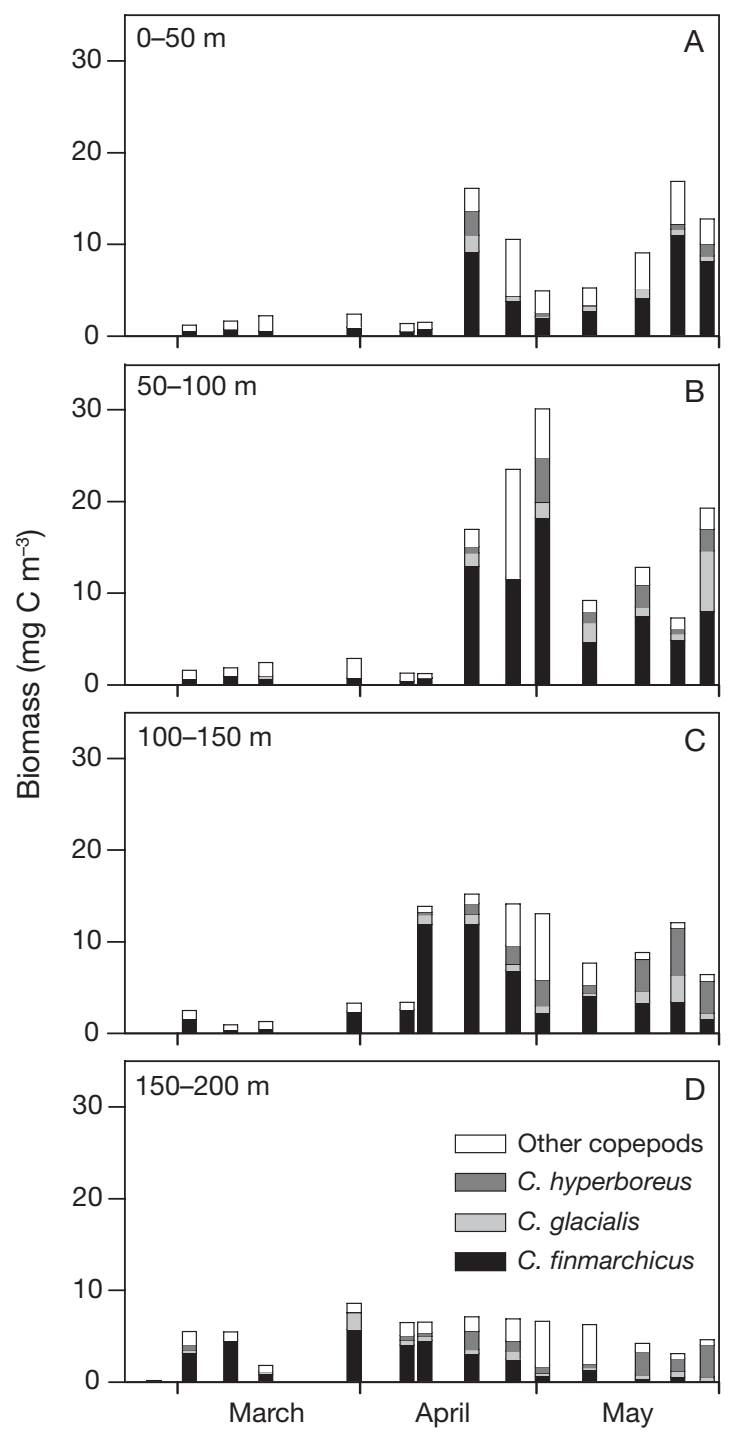

Fig. 4. Calanus spp. and other copepods. Vertical distribution and composition of the copepod biomass in 4 depth strata: (A) 0-50 m, (B) 50-100 m, (C) 100-150 m, and (D) 150-200 m 
to the integrated copepod biomass (0 to $200 \mathrm{~m}$ ). C. finmarchicus was by far the most abundant species, responsible for on average $75 \pm 4 \%$ of the integrated Calanus biomass, with the other $25 \%$ equally divided between C. glacialis and C. hyperboreus. The group of 'other copepods' primarily consisted of Pseudocalanus sp., Metridia longa, and Oithona similis. Until midApril, the biomass of copepods was low and relatively constant at all depths. During April, the copepods gradually migrated towards the surface, and from April 20, the majority of the biomass was located above $100 \mathrm{~m}$, with a maximum biomass of $30 \mathrm{mg} \mathrm{C} \mathrm{m}^{-3}$ measured at 50 to $100 \mathrm{~m}$ depth on May 2 .

Calanus finmarchicus and C. glacialis arrived simultaneously to the surface layer, where they could be found in low proportions from the end of February (Fig. 5A,E). Both species exhibited a clear seasonal migration pattern, where a decline in the proportion of copepods in the deeper depth strata was followed by a rise in the proportion of copepods in the overlaying strata. The overall migration patterns for $C$. finmarchicus (Fig. 5A-D) and C. glacialis (Fig. 5E-H) were very similar, but with a tendency for $C$. glacialis to be located in deeper strata.

\section{In situ EP rate}

Despite simultaneous arrival to the surface layers, the spawning pattern differed significantly between

\section{C. finmarchicus}
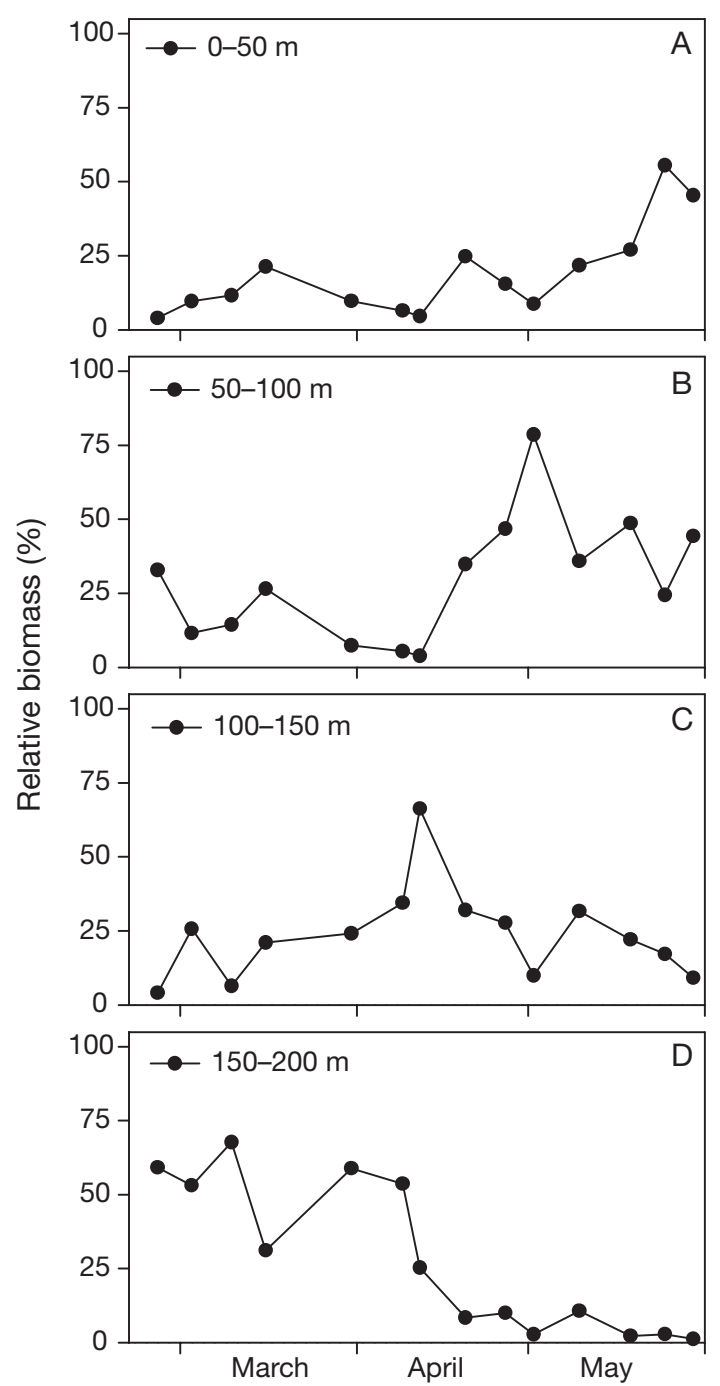

\section{C. glacialis}
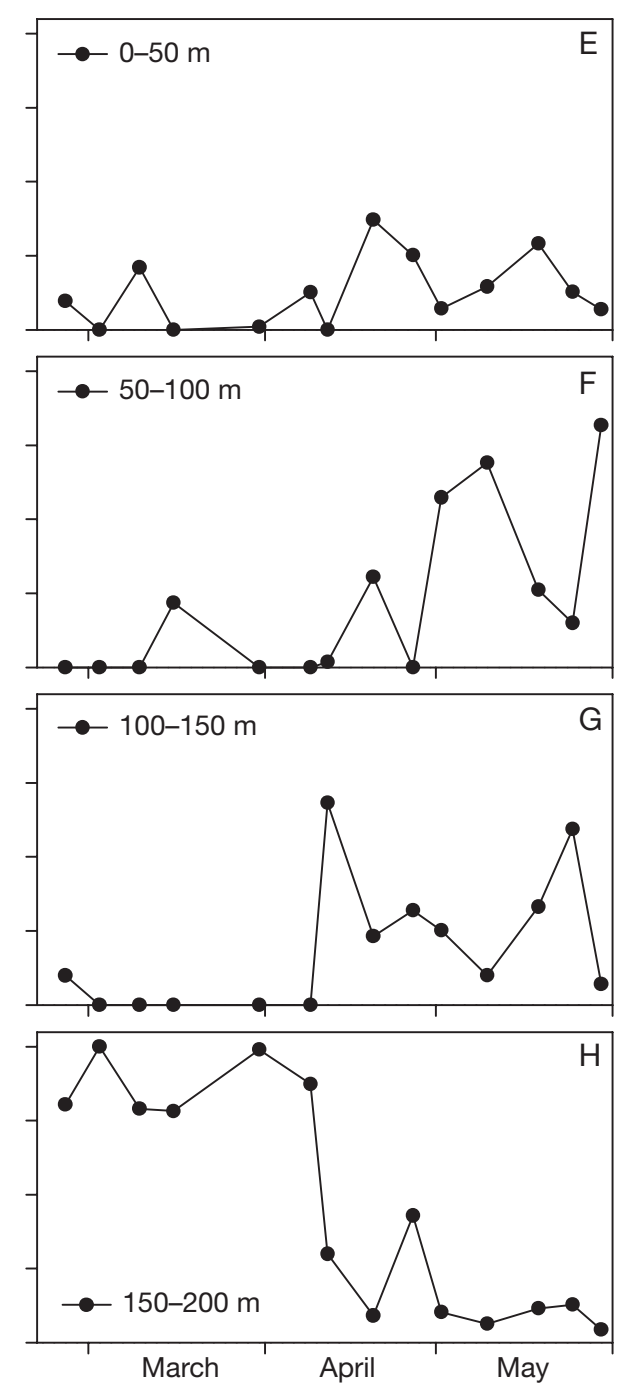

Fig. 5. Calanus finmarchicus and C. glacialis. Vertical distribution of the relative biomass (\% of total biomass) of (A-D) C. finmarchicus and (E-H) C. glacialis at 4 depth strata 
the 2 Calanus species. In late April, when EP experiments were initiated, $<25 \%(20 \pm 4 \%)$ of C. finmarchicus were spawning, and the EP rate was correspondingly low $\left(2.8 \pm 0.9\right.$ eggs female ${ }^{-1} \mathrm{~d}^{-1}$, Fig. $6 \mathrm{~B}, \mathrm{D})$. Thereafter the spawning percentage increased and $>90 \%$ of females were spawning at the beginning of May. However, EP did not peak before May $25\left(43.5 \pm 6.9\right.$ eggs female $\left.^{-1} \mathrm{~d}^{-1}\right)$, when the spring bloom was decreasing (Fig. 6A,F). Specific EP (SEP) varied between $0.16 \pm 0.12$ and $8.5 \pm 1.5 \mu \mathrm{g} \mathrm{C} \mu \mathrm{g} \mathrm{C}^{-1}$ $\mathrm{d}^{-1}$ (Fig. 6E) and clutch size was on average $23.8 \pm 2.1$ eggs, with the largest clutches found at the end of May (Fig. 6C). In contrast to C. finmarchicus, $>75 \%$ $(80 \pm 10 \%)$ of $C$. glacialis females were spawning by late April and EP reached a maximum of $48.3 \pm 8.3$ eggs female $\mathrm{e}^{-1} \mathrm{~d}^{-1}$ on May 1 , simultaneously with the
C. finmarchicus

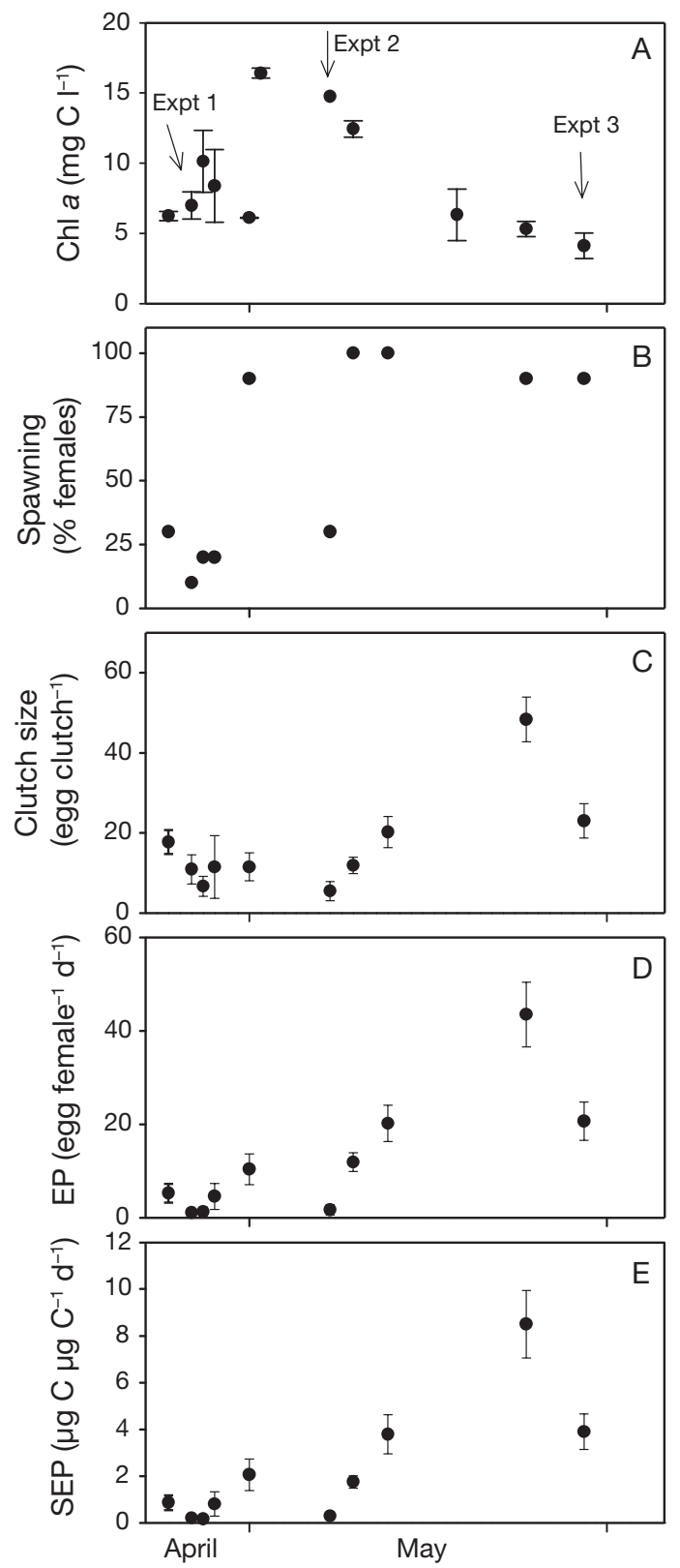

C. glacialis

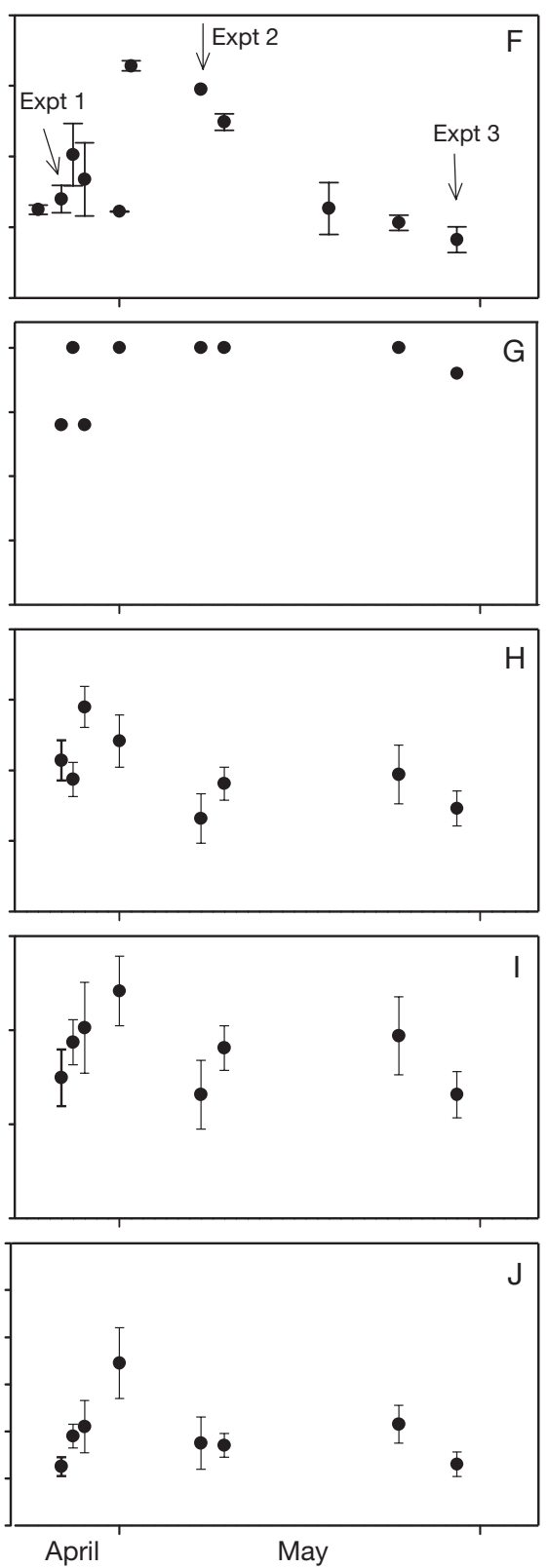

Fig. 6. Calanus finmarchicus and C. glacialis. Reproduction of (A-D) C. finmarchicus and (F-J) C. glacialis from April 24 to May 30, 2005 in Disko Bay. (A,F) Mean chlorophyll a concentrations at 1 and $15 \mathrm{~m}$; arrows indicate when females were collected for starvation experiments. $(\mathrm{B}, \mathrm{G})$ Percentage of actively spawning females; $(\mathrm{C}, \mathrm{H})$ clutch size; $(\mathrm{D}, \mathrm{I})$ in situ egg production $(\mathrm{EP})$; and

$(\mathrm{E}, \mathrm{J})$ specific egg production (SEP). Values are the means of 10 to 20 females. Error bars indicate $\pm \mathrm{SE}$ 
peak of the spring bloom (Fig. 6G,I). During May, average EP remained high $\left(31.7 \pm 2.9\right.$ eggs female $^{-1}$ $\mathrm{d}^{-1}$ ) and spawning percentage never dropped below $90 \%(98 \pm 2 \%)$. SEP for C. glacialis varied between $2.5 \pm 0.5$ and $7.0 \pm 1.5 \mu \mathrm{g} \mathrm{C} \mu \mathrm{C} \mathrm{C}^{-1} \mathrm{~d}^{-1}$ (Fig. 6J) and the average clutch size was $38 \pm 2$ eggs, with the largest clutches recorded from the end of April to the beginning of May (Fig. 6H).

There was no significant correlation between the EP of Calanus finmarchicus and C. glacialis and the biomass of any of the potential prey organisms, i.e. phytoplankton, protozooplankton, or total protist biomass. A day-by-day comparison of SEP rates between $C$. finmarchicus and C. glacialis revealed a significant difference in the reproductive activity over the season (Mann-Whitney $U$-test $\mathrm{p}<0.05$ ). C. glacialis was found to spawn earlier, with an EP peaking almost a month before that of $C$. finmarchicus.

\section{Laboratory experiments}

Expt 1 was initiated April 24 during the early phase of the spring bloom (Fig. 7). During the $10 \mathrm{~d}$ incubation, no differences in reproductive activity of Calanus finmarchicus females were detectable between the 2 food concentrations (Mann-Whitney $U$-test $\mathrm{p}>0.05$ ). The spawning percentage for the entire period aver-
C. finmarchicus
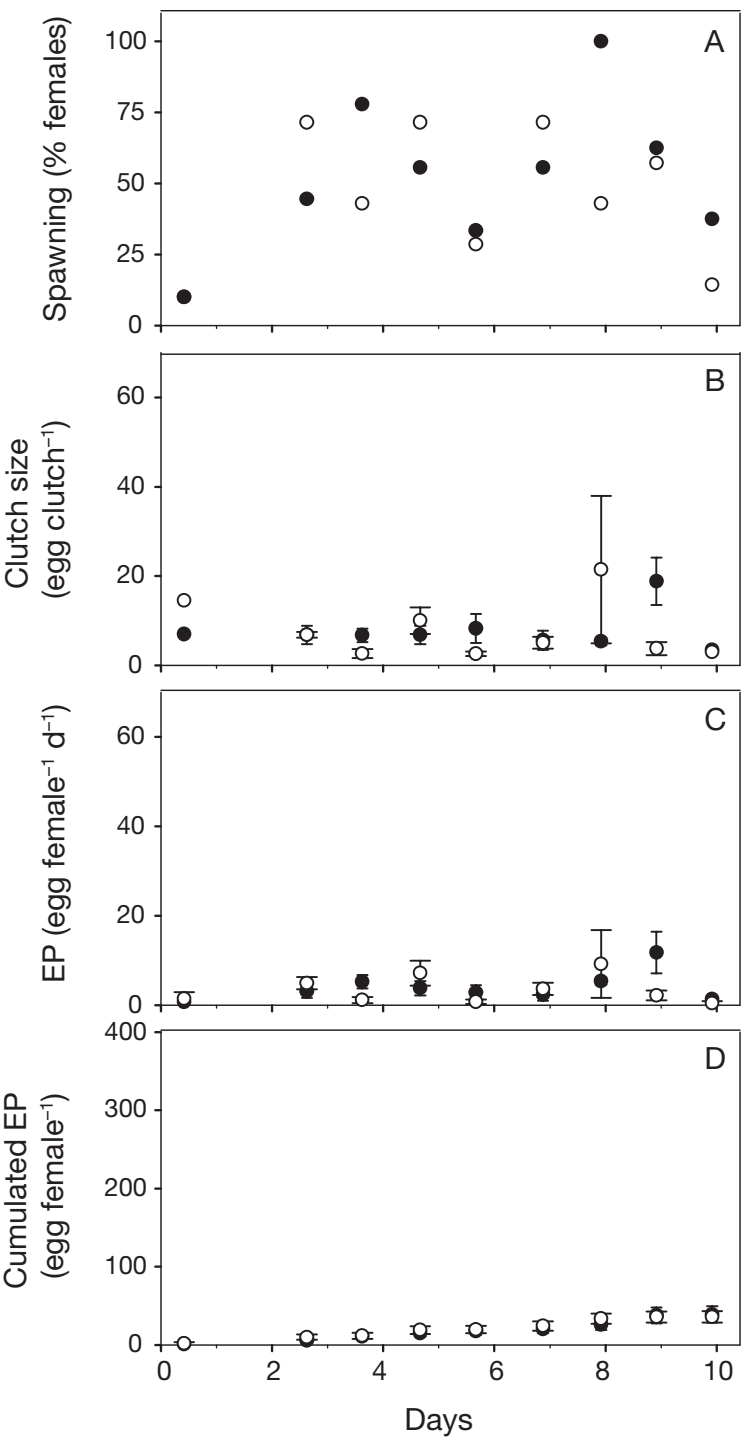

C. glacialis
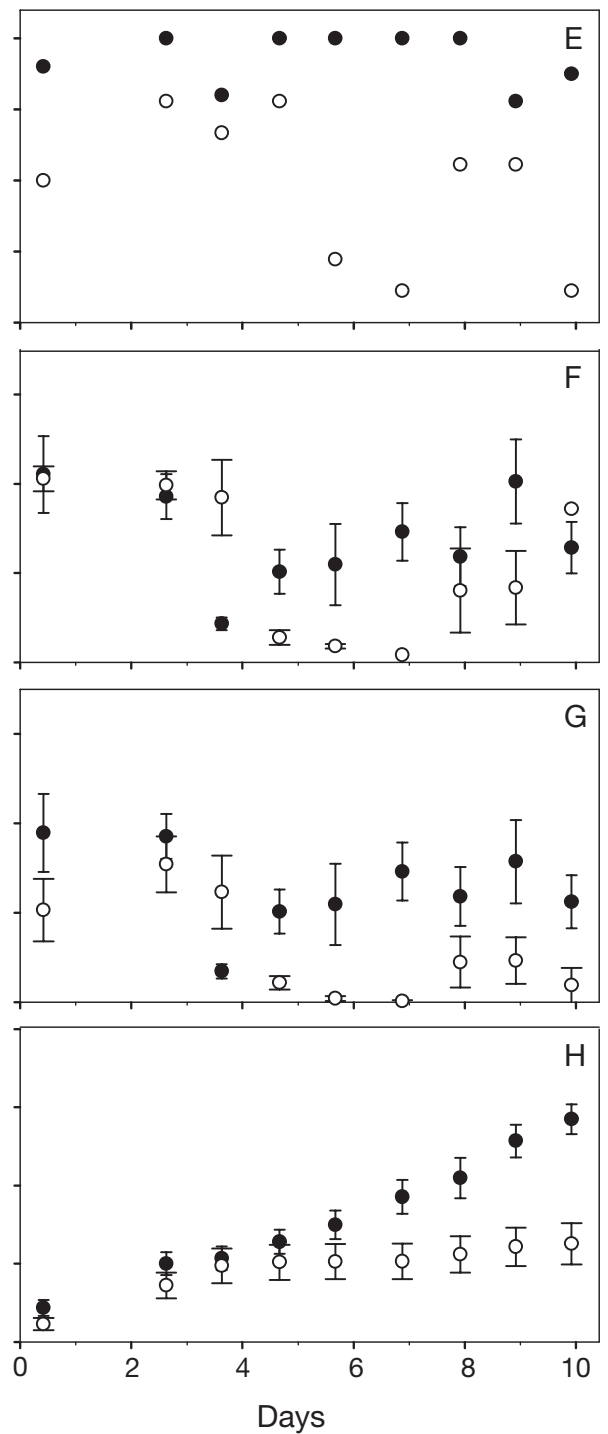

Fig. 7. Calanus finmarchicus, and C. glacialis. Expt 1. (A,E) Spawning \%; $(\mathrm{B}, \mathrm{F})$ clutch size; $(\mathrm{C}, \mathrm{G})$ egg production $(\mathrm{EP})$; and $(\mathrm{D}, \mathrm{H}) \mathrm{cu}-$ mulative EP for fed $(\bullet)$ and starved $(O)$ females during $238 \mathrm{~h}$ incubation. Values are mean of 10 females. Error bars indicate \pm SE 
aged $50 \%$ for both fed and starved females $(54 \pm 9$ and $46 \pm 8 \%$, respectively, Fig. 7A) and clutch size averaged $7.5 \pm 1$ and $7.7 \pm 1.8$ eggs, respectively (Fig. 7B). Rates of EP were $4.0 \pm 0.7$ for fed females and $3.4 \pm 0.9$ eggs female ${ }^{-1} \mathrm{~d}^{-1}$ for starved females (Fig. 7C), and cumulative EP after $10 \mathrm{~d}$ were $38.9 \pm 9.2$ and $35.9 \pm 6.3$ eggs female ${ }^{-1}$ for fed and starved females, respectively (Fig. 7D).

In contrast to Calanus finmarchicus, C. glacialis showed a clear decrease in reproduction due to starvation, with a significant difference in EP between fed and starved females after $5 \mathrm{~d}$ (Mann-Whitney $U$-test $\mathrm{p}<0.05)$. While the spawning percentage of fed females remained constant at $92.3 \pm 3.1 \%$ during the entire period, the spawning percentage for starved females averaged $68.1 \pm 6.6 \%$ the first $5 \mathrm{~d}$ and fell to $31.1 \pm 10.2 \%$ thereafter (Fig. 7E). Clutch sizes for fed and starved females were high the first $3 \mathrm{~d}$, averaging $39.5 \pm 3.2$ and $39.1 \pm 3$ eggs, respectively (Fig. 7F). Thereafter the clutch size for starved females fell to an average of $17.6 \pm 3.6$ eggs, whereas for fed females it was averaging $23.9 \pm 2.7$ eggs. As a consequence of the drastic decrease in the amount of females spawning and clutch size, EP for starved females dropped rapidly from averaging $20.1 \pm 3.4$ eggs female ${ }^{-1} \mathrm{~d}^{-1}$ after $5 \mathrm{~d}$, to an average of $4.6 \pm 1.8$ eggs female ${ }^{-1} \mathrm{~d}^{-1}$ (Fig. 7G). In contrast, EP for fed females remained at $25.1 \pm 3.3$ eggs female ${ }^{-1} \mathrm{~d}^{-1}$. Furthermore, starved females had a cumulative EP after $10 \mathrm{~d}$ which was half the size of the fed ones $(125 \pm 24$ and $285 \pm 17$ eggs, respectively), with differences between fed and starved females becoming significant after $6 \mathrm{~d}$ (Mann-Whitney $U$-test $\mathrm{p}<0.05$ ) (Fig. $7 \mathrm{H}$ ).

Expt 2 was initiated May 10 during the peak of the spring bloom, when both females of Calanus finmarchicus and C. glacialis had high EP rates (Fig. 8). Comparison of EP between fed and starved females revealed a significant effect of food concentration after 4 and $5 \mathrm{~d}$ for $C$. finmarchicus and C. glacialis, respectively (Mann-Whitney $U$-test $\mathrm{p}<0.05$ ). The proportion of $C$. finmarchicus females spawning was high from the beginning of the experiment, averaging $90 \pm 4.1 \%$ for fed females (Fig. 8A). For starved females, spawning percentage declined from $100 \%$ after $2 \mathrm{~d}$ to $50 \%$ after $11 \mathrm{~d}$, averaging $66.3 \pm 6.7 \%$. Clutch size averaged $33.5 \pm 2.7$ for fed and $15.3 \pm 1.9$ eggs for starved females (Fig. 8B). During the first $4 \mathrm{~d}$, no difference in EP between fed and starved females was observed (Mann-Whitney $U$-test $p>0.05$ ). Thereafter the difference became significant as EP for fed females increased to average $33.3 \pm 3.3$ eggs female ${ }^{-1} \mathrm{~d}^{-1}$ for the remainder of the experiment, while for starved females it averaged $9.3 \pm 1.8$ eggs female ${ }^{-1} \mathrm{~d}^{-1}$ (Fig. 8C). This resulted in a 3-fold higher cumulative EP after $11 \mathrm{~d}$ for fed females ( $342 \pm 26$ eggs) than for starved females
$(118 \pm 40$ eggs $)$, with differences becoming significant after $4 \mathrm{~d}$ (Mann-Whitney $U$-test $\mathrm{p}<0.05$ ) (Fig. 8D).

The proportion of fed Calanus glacialis females spawning remained approximately constant during the experiment, averaging $94.3 \pm 1.7 \%$ (Fig. 8E). Spawning percentage for starved females was high the first $5 \mathrm{~d}$, averaging $92.5 \pm 4.8 \%$, after which it dropped to average $44.3 \pm 2.8 \%$. Clutch size of fed females was on average $30.4 \pm 2.8$ eggs, while clutch size for starved females averaged $22.4 \pm 3.5$ eggs (Fig. 8F). Consequently the rate of EP for fed and starved females was similar the first $5 \mathrm{~d}$, after which it became significantly different (Mann-Whitney $U$-test $\mathrm{p}<0.05$ ) (Fig. 8G). EP for starved females dropped from an average of $27.0 \pm$ 5.0 to an average of $5.3 \pm 1.5$ eggs female ${ }^{-1} \mathrm{~d}^{-1}$, while for fed females it remained high, averaging $29.2 \pm$ 2.7 eggs female ${ }^{-1} \mathrm{~d}^{-1}$. Cumulative EP after $11 \mathrm{~d}$ was $324.3 \pm 40.6$ and $154.7 \pm 40.3$ eggs female ${ }^{-1}$ for fed and starved females, respectively, with a difference observable after $7 \mathrm{~d}$ (Mann-Whitney $U$-test $\mathrm{p}<0.05$ ) (Fig. 8H).

Expt 3 was initiated on May 30 after the spring bloom (Fig. 9). The data for both Calanus finmarchicus and C. glacialis showed a decrease in reproduction, with only minor differences between fed and starved females recorded. The proportion of $C$. finmarchicus females spawning varied considerably during the experiment, averaging $87.1 \pm 3.4$ and $74.3 \pm 5.3 \%$ for fed and starved females, respectively (Fig. 9A). Differences in clutch size and EP were small, with a tendency for values for starved females to be lower than for fed females (Fig. 9B,C). Mean clutch size and EP rate for starved females were $14 \pm 1.7$ eggs and $10.4 \pm$ 1.4 eggs female ${ }^{-1} \mathrm{~d}^{-1}$, respectively, and for fed females were $18 \pm 1.3$ eggs and $15.7 \pm 1.3$ eggs female ${ }^{-1} \mathrm{~d}^{-1}$, respectively. That added up to a cumulative EP after $13 \mathrm{~d}$ of $210.6 \pm 21.8$ eggs for fed females and $116.7 \pm$ 13.7 eggs for starved females (Fig. 9D). EP rate between fed and starved females did not differ significantly in this experiment, but by comparing the cumulated EP curves, differences were observed after $8 \mathrm{~d}$ (Mann-Whitney $U$-test $\mathrm{p}<0.05$ ).

The proportion of Calanus glacialis females spawning averaged $92.5 \pm 3.9$ for fed females and $69.3 \pm 6.7 \%$ for starved females (Fig. 9E). Also here, differences in clutch size and EP between fed and starved females were found to be small (Fig. 9F,G). Mean clutch size and EP rate for starved females were $14.3 \pm 1.8$ eggs and $9.8 \pm 1.4$ eggs female ${ }^{-1} \mathrm{~d}^{-1}$, respectively, and for fed females were $16.6 \pm 1.4$ egg and $15.3 \pm 1.4$ eggs female $\mathrm{e}^{-1} \mathrm{~d}^{-1}$, respectively. That added up to a cumulative EP after $13 \mathrm{~d}$ of $194.4 \pm 18.5$ eggs for fed females and $119.4 \pm 14.9$ eggs for starved females, with differences between fed and starved females noted only in the cumulative EP curves after $7 \mathrm{~d}$ (Mann-Whitney $U$-test $\mathrm{p}<$ 0.05) (Fig. 9H). 
C. finmarchicus
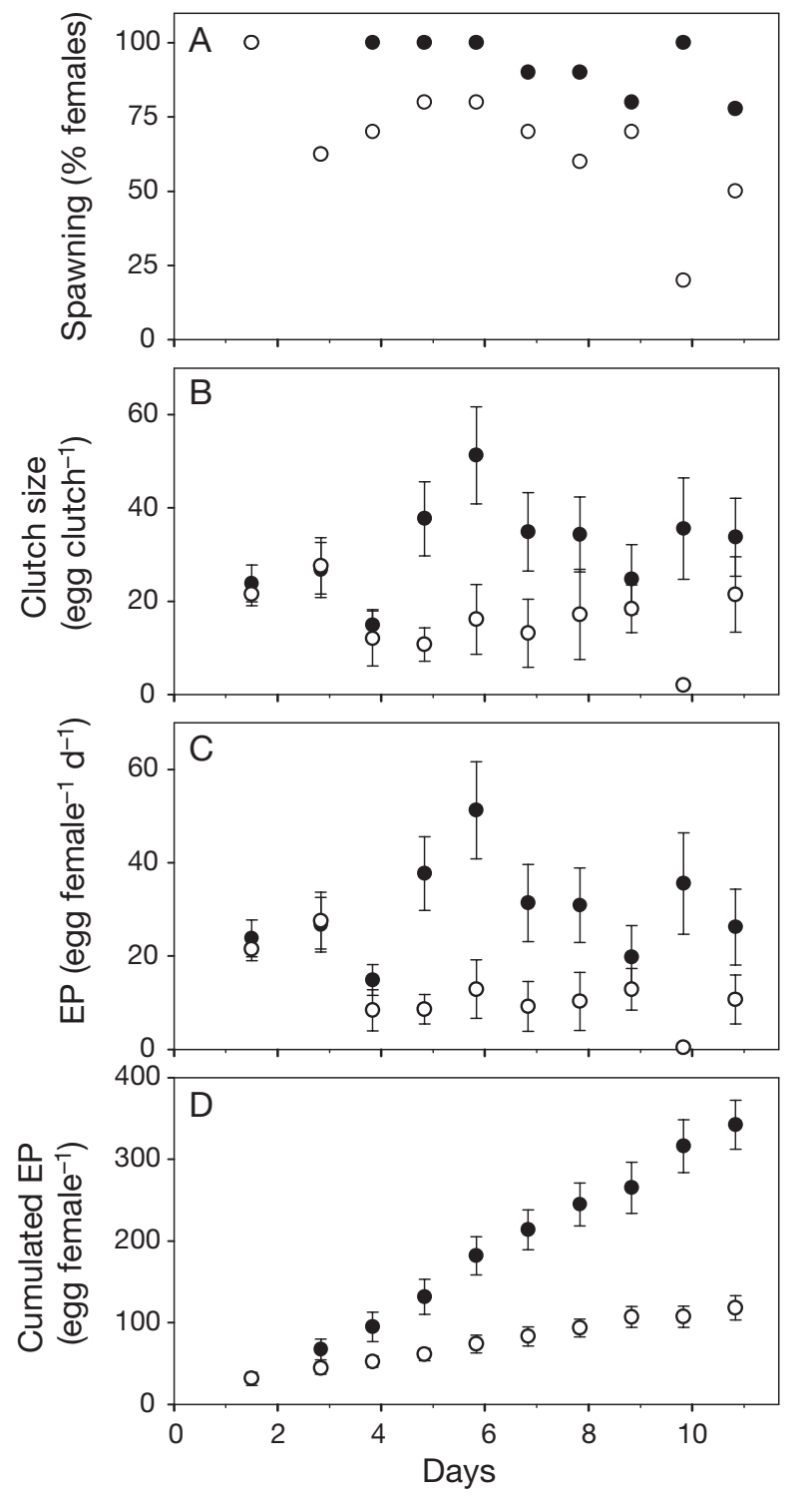

C. glacialis
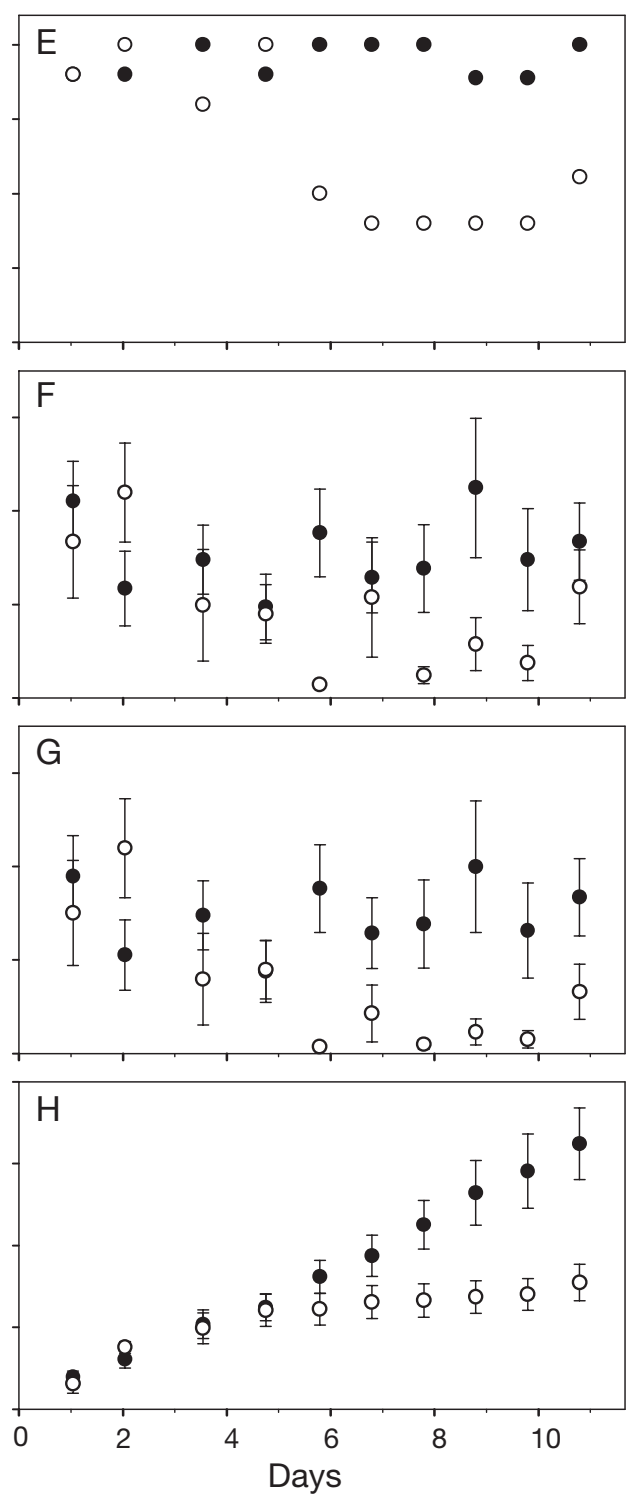

Fig. 8. Calanus finmarchicus and C. glacialis. Expt 2. (A,E) Spawning \%; (B,F), clutch size; (C,G), egg production (EP); and (D,H) cumulative EP for fed $(\bullet)$ and starved $(O)$ females during $260 \mathrm{~h}$ incubation. Values are mean of 10 females. Error bars indicate $\pm \mathrm{SE}$

\section{Effect of season}

The effects of food concentration on EP rate were different between the 3 experiments. The slopes of the cumulative EP curves of copepods of the same species held under the same experimental conditions were compared using a $t$-test. Significant differences $(\mathrm{p}<$ 0.01 or 0.02 ) were detected between all curves except between fed Calanus glacialis females in Expts 1 and 2, starved C. glacialis females in Expts 1 and 2, and starved C. finmarchicus females in Expts 2 and 3 (Table 3).
Table 3. Calanus finmarchicus and C. glacialis. Significance levels for $t$-test comparisons of the slopes of the cumulative egg production (EP) curves. ns: not significant

\begin{tabular}{|llccc|}
\hline \multirow{2}{*}{ Cumulative EP } & \multicolumn{2}{c|}{ C. finmarchicus } & \multicolumn{2}{c|}{ C. glacialis } \\
& Fed & Starved & Fed & Starved \\
\hline Expt $1><$ Expt 2 & 0.01 & 0.01 & ns & ns \\
Expt $1><$ Expt 3 & 0.01 & 0.01 & 0.01 & 0.02 \\
Expt 2><Expt 3 & 0.01 & ns & 0.01 & 0.01 \\
\hline
\end{tabular}


C. finmarchicus

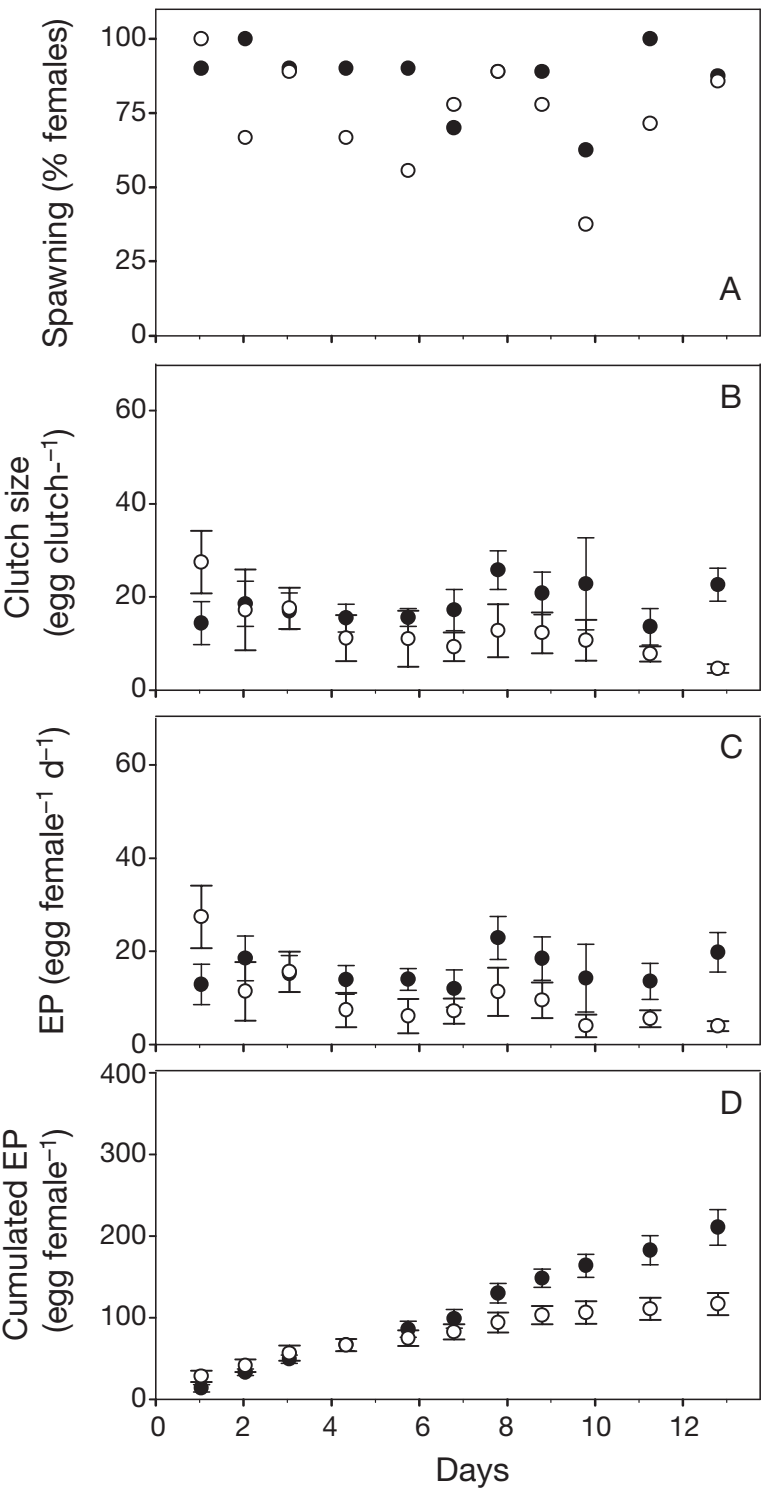

C. glacialis
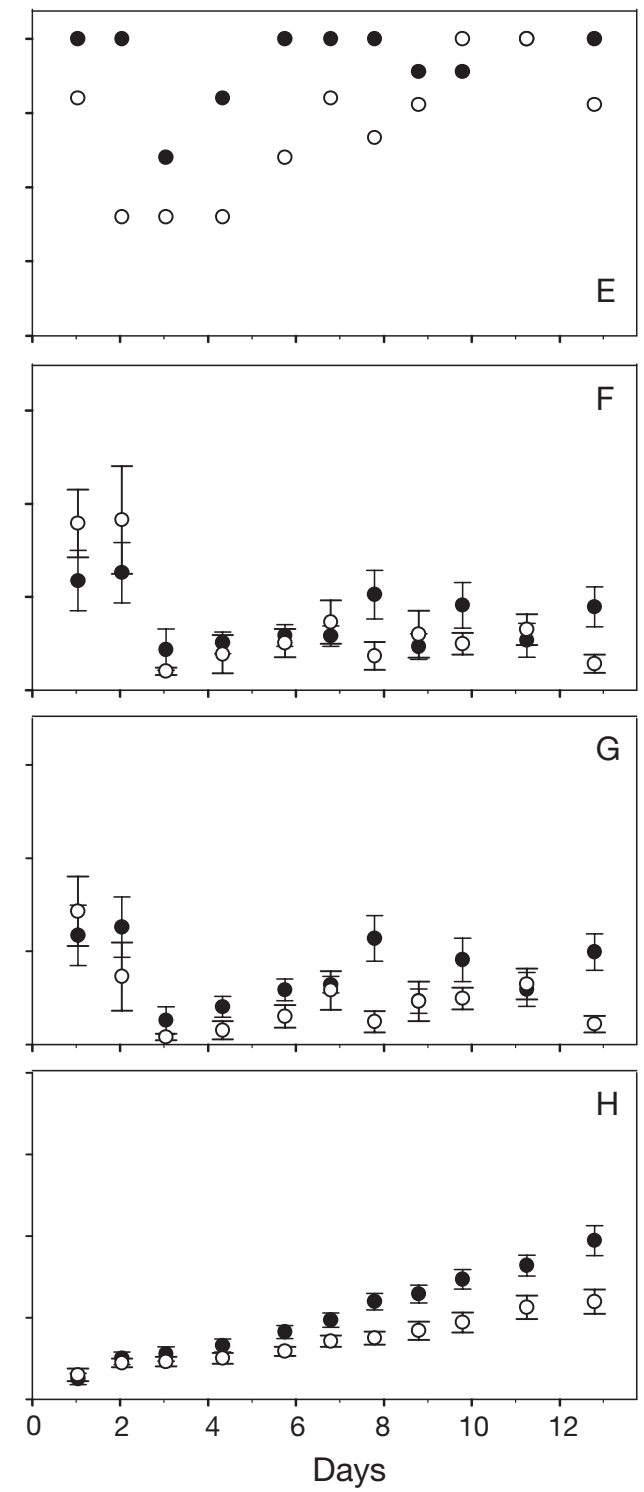

Fig. 9. Calanus finmarchicus and C. glacialis. Expt 3. (A,E) Spawning \%; $(\mathrm{B}, \mathrm{F})$, clutch size; $(\mathrm{C}, \mathrm{G})$, egg production $(\mathrm{EP})$; and $(\mathrm{D}, \mathrm{H})$, cumulative EP for fed $(\bullet)$ and starved $(O)$ females during $307 \mathrm{~h}$ incubation. Values are mean of 10 females. Error bars indicate $\pm \mathrm{SE}$

\section{DISCUSSION}

\section{The plankton community}

The spring bloom is the trigger for the pelagic production cycle and is the single most important event determining the production capacity of arctic marine food webs. The onset of the bloom varies between years depending on the duration of ice cover and the meteorologic conditions. In Disko Bay, the duration of ice cover is highly variable from year to year (HeideJørgensen et al. 2007). In 1992, the break-up of sea ice occurred in mid-May, with the subsequent bloom peaking in late June (Nielsen \& Hansen 1995), whereas in 2005 during our study, no stable sea ice was formed and the bloom developed early. During the present investigation, the spring bloom was triggered by a salinity-based stratification in late April, and peaked in early May. Duration of the bloom was around $2 \mathrm{wk}$, after which nitrate was depleted from the photic zone.

The estimated protozoan biomass was within the range of estimations from earlier years, and maximum biomass was found during the spring bloom (Levinsen 
et al. 2000). Top-down control by omnivorous copepods often regulates the protozooplankton community after the spring bloom when phytoplankton biomass is low (Levinsen \& Nielsen 2002). During the spring bloom, the copepods are primarily herbivores, as phytoplankton is by far the most abundant food resource (Levinsen et al. 2000).

As previously documented (Nielsen \& Hansen 1995, Madsen et al. 2001, Thor et al. 2005), we found that copepods dominated the mesozooplankton, and the copepod community was dominated by Calanus spp. In the upper $50 \mathrm{~m}$, the highest biomasses were found during the spring bloom, and were comparable to previous values measured in the area (Madsen et al. 2001). C. finmarchicus was by far the most abundant species of Calanus, responsible for $75 \%$ of the Calanus biomass, which differs from previous observations in which the 3 Calanus species were found in equal biomasses (Madsen et al. 2001). C. finmarchicus and C. glacialis exhibited a clear migration pattern and entered the surface layers simultaneously at the end of February, 2 mo before the development of the spring bloom.

The timing of the reproductive cycle in relation to the spring bloom confirmed results of previous investigations of life cycles and reproductive strategies of Calanus finmarchicus and C. glacialis. (Nielsen \& Hansen 1995, Madsen et al. 2001, Niehoff et al. 2002), i.e. C. glacialis was observed spawning prior to the spring bloom, with highest EP coinciding with the phytoplankton spring bloom, whereas the EP of $C$. finmarchicus was low prior to the bloom and peaked after termination of the bloom. The highest EP rates were similar or higher than previously measured rates from Disko Bay (Nielsen \& Hansen 1995, Madsen et al. 2001, Thor et al. 2005), but still within range of EP rates recorded from other arctic areas (Hirche 1990, Hirche \& Kwasniewski 1997, Kosobokova \& Hirche 2001).

\section{Effect of food}

The 2 Calanus species responded differently to the manipulated food concentrations and a clear effect of season on the female's ability to exploit the elevated food concentrations and endure starvation was observed. The copepods from Disko Bay were able to withstand starvation considerably longer than previous reported. Starved C. finmarchicus reproduced unaffected for $4 \mathrm{~d}$, twice as long as that found in starvation studies by Hirche (1990) and Hirche et al. (1997) at similar temperatures. C. glacialis females were found to withstand starvation for 5 to $6 \mathrm{~d}$ before EP was reduced, which was 2 to 3 times longer than previously observed. Other studies conducted at $0^{\circ} \mathrm{C}$ have re- corded response times at 2 d (Hirche 1989, Hirche \& Kwasniewski 1997, Kosobokova \& Hirche 2001, 2003), and experiments with females from Fram Strait have showed a decrease in EP rate after only $24 \mathrm{~h}$ of starvation (Hirche \& Bohrer 1987). The observed decrease in EP following starvation could mainly be explained by the decrease in clutch size and percentage of females spawning, reported by Niehoff $(2000,2004)$. Spawning intervals were not measured in the present study, but have previously been shown to be affected negatively by starvation (Hirche et al. 1997). The responses to the manipulated food concentration varied between the 3 experiments according to the in situ conditions of the collected females in terms of maturity and feeding history. C. finmarchicus collected in the early phase of the spring bloom (Expt 1, Fig. 7) had a very low EP, as was expected from the in situ measurements (Fig. 6) and previous studies (Nielsen \& Hansen 1995, Madsen et al. 2001), and no effect of food concentration on EP was observed. The lack of response in Expt 1 was probably due to the short feeding history of the females, as the initial gonad maturation seems to be dependent on freshly ingested food and the females consequently were not ripe (Niehoff 2004). Females collected during the peak of the spring bloom (Expt 2, Fig. 8) maintained high EP in the bottles with saturated food concentrations, whereas EP of the females incubated without food decreased to a minimum after $4 \mathrm{~d}$. C. glacialis females were reproducing at rates close to maximum, both in the early phase and during spring bloom (Expts 1 and 2), with EP of the starving females decreasing after $5 \mathrm{~d}$. In late May when the last experiment was initiated (Expt 3, Fig. 9), the in situ EP rate of both species had dropped to a lower level (Fig. 6). Compared to Expt 2 (Fig. 8), fed females were producing around $40 \%$ fewer eggs during the incubation period, whereas the decrease seen in the cumulative EP of the starved females was less obvious. Females of both C. finmarchicus and C. glacialis maintained unaffected EP for 6 to $8 \mathrm{~d}$ during starvation. Comparison of the slopes between the cumulative EP curves revealed that this was not the response to starvation that had changed between the 2 experiments, but rather the precondition of the females to exploit the food. It can be hypothesized that the females had become less sensitive to changes in food conditions because of an ability to recycle part of the established lipid, or that a part of the ingested food was being used to refuel lipid stores in preparation for the coming hibernation period instead of being allocated to EP. Even though the EP rate for fed females during Expt 3 had decreased profoundly, it was still in the range of in situ rates obtained by Madsen et al. (2001) in the post-bloom situation.

In conclusion, both species investigated entered the surface layer prior to the development of the spring 
bloom and depended on food to maintain maximal EP. Before the spring bloom, Calanus finmarchicus was less able to handle an extended period of starvation than was C. glacialis, but once the bloom was underway, both species had a similar response to starvation. Females of C. glacialis and C. finmarchicus from Disko Bay seemed to be capable of enduring considerably longer starvation periods than females collected from other areas before lipid stores were exhausted and an effect on reproductive output was observed. This could be an adaptive response to the highly unpredictable environment of Disko Bay, and a possible explanation of the reproductive success of the Atlantic copepod $C$. finmarchicus in this Arctic area.

The strategy of Calanus glacialis to spawn prior to the spring bloom could be an adaptation to the unpredictable food conditions in the arctic environment with oscillating ice cover. In a future warmer climate, the initiation of the spring bloom will be more predictable, as the bloom will develop according to the light cycle rather than the ice break-up. In such a scenario, the advantages of early spawning could change to a burden in the competition with the co-occurring $C$. finmarchicus. Consequently, in a warmer future, the smaller, faster-growing $C$. finmarchicus with a shorter life cycle could have an advantage and take over as the dominating copepod in this Arctic ecosystem.

Acknowledgements. This study was supported by DANCEA and the Danish National Research Council (grant \#21-040391 to TGN). The Arctic station Qeqertarsuaq, University of Copenhagen, provided an excellent working platform on land. F. Grønvold, captain of MS 'Porsild' and his staff provided great technical support at sea. We greatly acknowledge J. Larsen for skilled technical assistance. M. Maar and P. Thor are acknowledged for comments to an earlier version of the manuscript.

\section{LITERATURE CITED}

Conover RJ (1988) Comparative life histories in the genera Calanus and Neocalanus in high latitudes of the northern hemisphere. Hydrobiologia 167/168:127-142

Fiksen $\varnothing ~(2000)$ The adaptive timing of diapause: a search for evolutionarily robust strategies in Calanus finmarchicus. ICES J Mar Sci 57:1825-1833

Grasshoff K (1976) Methods for seawater analysis. Weinheim, New York

Hansen AS, Nielsen TG, Levinsen H, Madsen SD, Thingstad TF, Hansen BW (2003) Impact of changing ice cover on pelagic productivity and food web structure in Disko Bay, West Greenland: a dynamic model approach. Deep-Sea Res I 50:171-187

Hansen BW, Nielsen TG, Levinsen H (1999) Plankton community structure and carbon cycling on the western coast of Greenland during the stratified summer situation. III. Mesozooplankton. Aquat Microb Ecol 16:233-249

Heide-Jørgensen MP, Acquarone M (2002) Size and trends of the bowhead, beluga and narwhal stocks wintering off West Greenland. Sci N Atl Mar Mamm Comm 4:191-210
Heide-Jørgensen MP, Laidre KL, Logsdon ML, Nielsen TG (2007) Springtime coupling between phytoplankton, sea ice, and sea surface temperature in Disko Bay, West Greenland. Progr Oceanogr 73:79-95

Hirche HJ (1989) Egg production of the Arctic copepod Calanus glacialis: laboratory experiments. Mar Biol 103: 311-318

Hirche HJ (1990) Egg production of Calanus finmarchicus at low temperature. Mar Biol 106:53-58

Hirche HJ, Bohrer RN (1987) Reproduction of the Arctic copepod Calanus glacialis in Fraim Strait. Mar Biol 94:11-17

Hirche HJ, Kosobokova K (2003) Early reproduction and development of dominant calonoid copepods in the sea ice zone of the Barents Sea: Need for a change of paradigms? Mar Biol 143:769-781

Hirche HJ, Kwasniewski S (1997) Distribution, reproduction and development of Calanus species in the Northeast Water in relation to environmental conditions. J Mar Syst 10:299-317

Hirche HJ, Niehoff B (1996) Reproduction of the Arctic copepod Calanus hyperboreus in the Greenland Sea: field and laboratory observations. Polar Biol 16:209-219

Hirche HJ, Baumann MEM, Kattner G, Gradinger R (1991) Plankton distribution and the impact of copepod grazing on primary production in Fram Strait, Greenland Sea. J Mar Syst 2:477-479

Hirche HJ, Meyer U, Niehoff B (1997) Egg production of Calanus finmarchicus: effect of temperature, food and season. Mar Biol 127:609-620

Jespersen AM, Christoffersen K (1987) Measurements of chlorophyll-a from phytoplankton using ethanol as extraction solvent. Arch Hydrobiol 109(3):445-454

Karnovsky N, Kwasniewski S, Weslawski JM, Walkusz W, Beszczynska-Möller A (2003) The foraging behaviour of little auks in a heterogenous environment. Mar Ecol Prog Ser 253:289-303

Kosobokova K, Hirche HJ (2001) Reproduction of Calanus glacialis in the Laptev Sea, Arctic Ocean. Polar Biol 24: 33-43

Lee RF, Hagen W, Kattner G (2006) Lipid storage in marine zooplankton. Mar Ecol Prog Ser 307:273-306

Levinsen H, Nielsen TG (2002) The trophic role of marine pelagic ciliates and heterotrophic dinoflagellates in arctic and temperate coastal ecosystems: a cross-latitude comparison. Limnol Oceanogr 47(2):427-439

Levinsen H, Turner JT, Nielsen TG, Hansen BW (2000) On the trophic coupling between protists and copepods in arctic marine ecosystems. Mar Ecol Prog Ser 204:65-77

Madsen SD, Nielsen TG, Hansen BW (2001) Annual population development and production by Calanus finmarchicus, C. glacialis and C. hyperboreus in Disko Bay, western Greenland. Mar Biol 139:75-93

Menden-Deuer S, Lessard EJ (2000) Carbon to volume relationships for dinoflagellates, diatoms and other protist plankton. Limnol Oceanogr 45:569-579

Møller EF, Nielsen TG, Richardson K (2005) The zooplankton community in the Greenlandic Sea: composition and role of carbon turnover. Deep-Sea Res I 53:76-93

Niehoff B (2000) Effect of starvation on the reproductive potential of Calanus finmarchicus. ICES J Mar Sci 57: 1764-1772

Niehoff B (2004) The effect of food limitation on gonad development and egg production of the planktonic copepod Calanus finmarchicus. J Exp Mar Biol Ecol 307:237-259

Niehoff B, Madsen SD, Hansen BW, Nielsen TG (2002) Reproductive cycles of three dominant Calanus species in Disko Bay, West Greenland. Mar Biol 140:567-576 
Nielsen TG, Hansen B (1995) Plankton community structure and carbon cycling on the western coast of Greenland during and after the sedimentation of a diatom bloom. Mar Ecol Prog Ser 125:239-257

Nielsen TG, Hansen PJ (1999) Dyreplankton i Danske farvande TEMA-rapport fra DMU. Miljø-og Energiministeriet, Copenhagen

Nielsen TG, Ottosen LD, Hansen BW (2007) Structure and function of the pelagic ecosystem in Young Sound, NE Greenland. In: Rysgaard S, Glud RN (eds) carbon cycling in Arctic marine ecosystems: case study Young Sound. Meddeleser om Grønland Bioscience, Vol 58. Danish Polar Center, Copenhagen, p 88-107

Editorial responsibility: Matthias Seaman (Assistant Editorin-Chief), Oldendorf/Luhe, Germany
Pedersen TJ, Nielsen TG, Michel C, Møller EF and others (2006) Sedimentation following the spring bloom in Disko Bay, West Greenland, with special emphasis on the role of copepods. Mar Ecol Prog Ser 314:239-255

Smith SL (1990) Egg production and feeding by copepods prior to the spring bloom of phytoplankton in the Fram Strait area of the Greenland Sea. Mar Biol 106:59-69

Thor P, Nielsen TG, Tiselius P, Juul-Pedersen T and others (2005) Post-spring bloom community structure of pelagic copepods in the Disko Bay, Western Greenland. J Plankton Res 27(4):341-356

Thorisson K (2006) How are the vertical migration of copepods controlled? J Exp Mar Biol Ecol 329:86-100

Submitted: January 2, 2007; Accepted: June 25, 2007

Proofs received from author(s): December 19, 2007 